\title{
Determinants of Purchasing Halal Food for Housewives
}

\author{
Dian Kristina ${ }^{1}{ }^{*}$, Arna Asna Annisa ${ }^{1}$, and Awangku Muhamad Zul Iskandar Bin Pengiran \\ Zulkifli $^{2}$ \\ ${ }^{1}$ Faculty of Islamic Economics and Business, IAIN Salatiga, Indonesia \\ ${ }^{2}$ Universiti Islam Sultan Sharif Ali, Brunei Darussalam
}

\begin{abstract}
This study aims to determine how the influence of Lifestyle, Religiosity, Product Quality on Purchase Decisions in the Tokopedia application through buying interest as an intervening variable. In this study, data collection was carried out through the provision of questionnaires distributed and filled out by housewives who had used and made buying and selling transactions at Tokopedia in Semarang Regency. This type of research uses quantitative research. Data analysis in this study consisted of classical assumption test, instrument test, statistical test, path analysis test which was processed through the SPSS application. With the results of the test of all variables, it can be shown that the easier technology is to influence the purchasing decisions of housewives in meeting family needs, especially in fulfilling halal food.
\end{abstract}

\section{Introduction}

The COVID-19 pandemic has occurred all over the world. It's been two years, the whole world and especially Indonesia have been affected by COVID-19 so far. This changes the order of life in terms of the economy, health, and others. Social activities are postponed for some time, until they become completely limited, and this condition changes the consumption patterns that occur in society. The era of globalization and growing information can change people's consumption patterns that are increasingly following the current trend. This can make it easier for people to make online shopping transactions easily. The increase occurred in online trading platforms of up to $38.5 \%$ during the pandemic, the data is according to records reported by Exabytes, a hosting service provider in Indonesia (Juniar \& Uci, 2021).

Lifestyle is an influence on the pattern of today's society. Lifestyle is a pattern of life in society both in activities, interests and income in spending money (Sumarwan,2004). Technology and information are advancing and developing all the time. Trends are very inherent in society, with advances in technology and information being advanced, and this is related to the rise of online shopping activities. Without realizing it, the emergence of this marketplace has changed our lifestyle. Now only with a smartphone, we can buy the goods or food we want easily and quickly (Sudjatmika, 2017).

\footnotetext{
* Corresponding author: dianakristi98@gmail.com
} 


\section{$A I C \overline{I E B} \quad$ Annual International Conference \\ on Islamic Economics and Business, 2021}

The family is the smallest community group that influences the pattern of life, and housewives are the main regulators of what is needed in a family both taking care of, nurturing according to patterns that have been embedded in the general public. Housewives are one of the shopper personas or groups of shoppers who have various behaviors (Juniar \& Uci, 2021). Through online buying and selling platforms, it is increasingly easier for consumers, especially housewives, to meet family needs, especially quality and food by finding and buying food products that are guaranteed to be halal in products that will be consumed by all family members. Besides, the condition of the community's economic resilience can be seen from how the family fulfills their needs. Some resilient individuals and social groups will not only survive in a certain condition but also develop. They will develop ways to turn stressful situations into opportunities for self-development (Romarina, 2016)

At the end of 2020, Tokopedia provides a special platform to sell products that have been certified halal by MUI. The provision of the platform was launched through a collaboration between Tokopedia, the Halal Product Assurance Agency (BPJPH), the Institute for the Study of Food, Drugs and Cosmetics of the Indonesian Ulema Council (LPPOM MUI). Head of Tokpedia Salam, Garri Juanda said Tokopedia provides services for the Muslim community to find various products, such as food, medicines, beverages, cosmetics, worship equipment, and clothing.

\section{Method}

The purpose of this study is to explain how the influence of buying interest on the decision to purchase halal food during the Covid-19 pandemic. The population in this study were housewives. Determination of the sample is done by using the technique. The number of samples is 100 respondents. The big theory used in this research is The Theory of Planned Behavior (TPB). This theory was developed to predict behavior that is not entirely under the control of an individual. The Theory of Planned Behavior (TPB) the concept describes the concept of perceived behavioral control, namely their ability to perform an action. The decision to make a choice where all behavior is considered, the consequences of each step are evaluated and a decision is made (Ajzen, 1991)

This study uses a quantitative approach. The data used are primary data obtained through the distribution of online questionnaires. The questionnaire was assessed using a 5-point Likert scale ( $1=$ strongly disagree, to $5=$ strongly agree). Meanwhile, the variables studied include lifestyle variables, religiosity, product quality, buying interest, and purchasing decisions. In Figure 1.1 the following is an overview of this research:

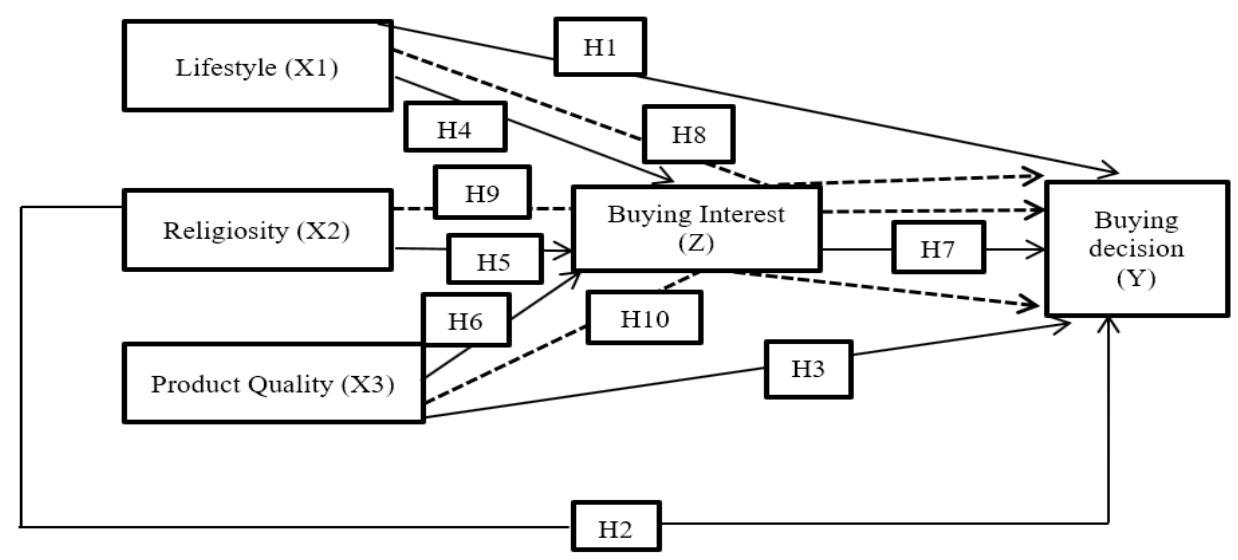


Fig 1. Research Framework

The results of the hypothesis developed in this study are as follows:

H1 : Lifestyle has a positive and significant effect on buying interest.

H2 : Religiosity has no significant positive effect on buying interest.

H3 : Product quality has a positive and significant effect on buying interest..

H4 : Lifestyle has no significant positive effect on purchasing decisions.

H5 : Religiosity has no significant positive effect on purchasing decisions.

H6 : Product quality has a positive and significant effect on purchasing decisions

H7 : Purchase interest has a positive and significant effect on purchasing decisions.

H8 : Lifestyle has no significant positive effect on purchasing decisions through buying interest as an intervening variable

H9 : Religiosity has no significant effect on purchasing decisions through buying interest as an intervening variable

H10 : Product quality has a positive and signicant decisions through buying interest as an intervening variable.

\section{Result and Discussion}

Figures and tables, as originals of good quality and well contrasted, are to be in their final form, ready for reproduction, pasted in the appropriate place in the text. Try to ensure that the size of the text in your figures is approximately the same size as the main text (10 point). Try to ensure that lines are no thinner than 0.25 point.

\subsection{Validity}

Validity test is a test to find out whether the questionnaire is valid or not (Sugiyono, 2015). Based on the results of the analysis, if the significance value is less than 0.05 , it can be said that the indicator is invalid and not suitable for research. Vice versa if the result of significance is more than 0.05 then it is said to be valid and feasible to use. Based on Table 1 , it can be seen that all variables have met the requirements and are declared valid.

Table 1. Validity Test

\begin{tabular}{|c|c|c|c|c|}
\hline Variabel & Question & r hitung & $\mathrm{r}$ tabel & Description \\
\hline \multirow{6}{*}{ Lifestyle (X1) } & Question 1 & $0,761 * *$ & \multirow{6}{*}{0,3009} & Valid \\
\hline & Question 2 & $0,426^{*}$ & & Valid \\
\hline & Question 3 & $0,515^{* *}$ & & Valid \\
\hline & Question 4 & $0,391 *$ & & Valid \\
\hline & Question 5 & $0,481 * *$ & & Valid \\
\hline & Question 6 & $0,543 * *$ & & Valid \\
\hline \multirow{2}{*}{ Religiosity(X2) } & Question 1 & $0,603 * *$ & \multirow{2}{*}{0,3009} & Valid \\
\hline & Question 2 & $0,372 *$ & & Valid \\
\hline
\end{tabular}









\begin{tabular}{|c|c|c|c|}
\hline & Question 3 & $0,441 *$ & Valid \\
\hline & Question 4 & $0,706 * *$ & Valid \\
\hline & Question 5 & $0,684 * *$ & Valid \\
\hline & Question 6 & $0,709 * *$ & Valid \\
\hline & Question 7 & $0,736 * *$ & Valid \\
\hline & Question 8 & $0,812 * *$ & Valid \\
\hline
\end{tabular}

\subsection{Reliability}

Table 2 is the result of the reliability test which is a test to measure the reliability of the questionnaire which contains indicators of the variables studied. Reliability test to measure the reliability of the questionnaire which contains indicators of the variables studied. The questionnaire is said to be good if the questionnaire remains consistent when taking measurements. SPSS provides facilities that can be used to measure reliability in questionnaires through statistical tests, and there is a technique used to measure reliability with Cronbach's Alpha $(\alpha)$ technique. The research instrument is said to be reliable by using this technique. with cronbach's alpha value $(\alpha)>0.6$ (Bawono, 2006).

Table 2. Reliability Test

\begin{tabular}{|l|c|c|}
\hline \multicolumn{1}{|c|}{ Variables } & Cronbach's Alpha & Description \\
\hline Lifestyle & 0.424 & Reliable \\
\hline Religiosity & 0.800 & Reliable \\
\hline Product Quality & 0.653 & Reliable \\
\hline Buying interest & 0.677 & Reliable \\
\hline $\begin{array}{l}\text { Purchasing } \\
\text { decisions }\end{array}$ & 0.782 & Reliable \\
\hline
\end{tabular}

\subsection{R Test}

Based on Table 3 below, it shows that the R-Square on the buying interest variable is 0.752 where lifestyle, religiosity, and product quality are 75 percent while 25 percent is explained by other variables outside the model. Furthermore, the R-Square value on the purchasing decision variable is 0.645 , where lifestyle, religiosity, product quality and buying interest are 64 percent, while 36 percent are influenced by other variables outside the model.

Table 3. R Square

\begin{tabular}{|l|c|c|}
\hline \multicolumn{1}{|c|}{ Variable } & R Square & R Square Adjusted \\
\hline Buying interest & 0.752 & 0,565 \\
\hline Purchasin decisions & 0.645 & 0.415 \\
\hline
\end{tabular}

\section{$3.4 \mathrm{~T}$ test}

Based on table 4, it can be explained that the lifestyle and product quality variables have a positive and significant effect on buying interest while the religiosity variable has a positive and insignificant effect on buying interest. The relationship between the buying interest variable on purchasing decisions has a significant positive effect, while the lifestyle and 


\section{$A \overline{I F B}$ Annual International Conference \\ on Islamic Economics and Business, 2021}

product quality variables have a non-significant positive effect on purchasing decisions and the religiosity variable has a negative and insignificant effect on purchasing decisions.

Table 4. T Test

\begin{tabular}{|c|c|c|c|c|}
\hline Variabel & $\begin{array}{c}\text { Unstandardized } \\
\text { Coefficients (B) }\end{array}$ & $\begin{array}{c}\text { Unstandardized } \\
\text { Coefficients } \\
\text { (Std Error) }\end{array}$ & t-value & p-value \\
\hline $\mathrm{GH}-\mathrm{MB}$ & 0.232 & 0.111 & 2.089 & 0.039 \\
\hline $\mathrm{R}-\mathrm{MB}$ & 0.009 & 0.107 & 0,080 & 0.936 \\
\hline $\mathrm{KP}-\mathrm{MB}$ & 0.477 & 0.075 & 6.368 & 0.000 \\
\hline $\mathrm{MB}-\mathrm{KP}$ & 0.334 & 0.001 & 3.293 & 0.001 \\
\hline $\mathrm{GH}-\mathrm{KP}$ & 0.116 & 0.113 & 1.027 & 0.307 \\
\hline $\mathrm{R}-\mathrm{KP}$ & $-0,014$ & 0.107 & -0.128 & 0.898 \\
\hline $\mathrm{KP}-\mathrm{KEP}$ & 0.143 & 0.089 & 1.610 & 0.111 \\
\hline $\mathrm{PEMB}$ & \multicolumn{3}{|l}{} \\
\hline
\end{tabular}

Based on the results of the analysis, the relationship between lifestyle variables and product quality has a significant influence on buying interest. This is supported by previous research conducted by Rumbiati \& Heriyana (2020) which states that lifestyle has a positive and significant influence on buying interest and previous research conducted by Tambunan (2019) which states that product quality has a positive and significant effect on purchase intention. While the relationship between the variables of religiosity on buying interest has a positive and insignificant effect, this is in line with previous research conducted byFauzia et al., (2019) which states that religiosity has no significant positive effect on buying interest.

Meanwhile, the relationship between lifestyle variables, religiosity, product quality has no significant effect on purchasing decisions. This is in line with previous research conducted by Sakdiyah et al., (2021) which states that lifestyle has an insignificant positive effect on purchasing decisions. Previous research conducted by Abdillah (2020) which states that religiosity has a negative and insignificant effect on purchasing decisions, and previous research conducted by Rawung et al., (2015) which states that product quality has no significant positive effect on purchasing decisions.

As explained earlier, it can be concluded that if the variables of lifestyle, religiosity, product quality and buying interest as intervening variables, the relationship between lifestyle variables and religiosity has a positive and insignificant effect, but the product quality variable has a positive and significant effect. This shows that it is important to form buying interest, even though it is not very significant, but it can influence the decision to buy halal.

\section{Conclusion}

Based on the results of the research and discussion above, it shows that for a direct effect, both lifestyle and religiosity have no significant effect on purchasing decisions. However, through the mediating role of buying interest, the product quality variable has a significant effect on purchasing decisions, but the lifestyle and religiosity variables have no significant positive effect. That is, before consumers make a decision, it is important for consumers to grow interest first, so that if they feel confident about halal food, it will be easier to make a decision.

The results of this study provide good input and recommendations for sellers and producers of halal food, especially in the halal corner of Tokopedia, in order to design and convince the public about the importance of consuming halal food. Consumers must have the knowledge to choose the products they want or will buy, so that aspects of product quality, product information, durability, and the type or form of attractive product packaging, 


\section{$A \overline{I E B} \quad$ Annual International Conference \\ on Islamic Economics and Business, 2021}

nutritional and health values in food will influence and increase people's buying interest to buy food. decided to buy the product. Especially the presence of a halal logo that makes it easier for people to choose products that have been certified halal by MUI.

The importance of campaigns and promotions about the importance of consuming halal food. related parties such as MUI, religious institutions in the community as well as scholars and religious leaders to provide material and knowledge to the community about the importance of this. With the increasing awareness of the public's mindset about the importance of halal food and products to be consumed, it will increase people's buying interest in making purchasing decisions for halal products that have been registered with the MUI.

\section{References}

Abdillah, L. J. (2020). Pengaruh Desain Produk, Citra Merek, Dan Religiusitas Terhadap Keputusan Pembelian Dengan Minat Beli Sebagai Variabel Intervening Pada Produk Maternal Disaster. In Skripsi. Salatiga: Fakultas Ekonomi dan Bisnis Islam IAIN Salatiga.

Ajzen, I. (1991). The theory of planned behavior. Organizational Behavior and Human Decision Processes, 50(2), 179-211. https://doi.org/10.1016/0749-5978(91)90020-T

Bawono, A. (2006). Miltivaiate Analysis Dengan SPSS. Stain Salatiga Press.

Fauzia, D. R. S., Pangestu, E., \& Bafadhal, A. S. (2019). Pengaruh religiusitas, sertifikasi halal, bahan produk terhadap minat beli dan keputusan pembelian. Jurnal Administrasi Bisnis (JAB), 66(1), 37-46.

Juniar, A. M., \& Uci, J. (2021). Belanja Online di Masa Pandemi Covid-19: Studi Kasus Ibuibu Rumah Tangga di Kota Makassar. Emik, 4(1), 37-51. https://doi.org/10.46918/emik.v4i1.850

Rawung, D. R., Oroh, S. G., \& Sumawauw, J. S. B. (2015). Analisis Kualitas Produk, Merek Dan Harga Terhadap Keputusan Pembelian Sepeda Motor Suzuki Pada Pt . Sinar Galesong Pratama Manado. Jurnal EMBA, 3(3), 1298-1308.

Romarina, A. (2016). Economic Resilience Pada Industri Kreatif Gunamenghadapi Globalisasi Dalam Rangka Ketahanan Nasional. Jurnal Ilmu Sosial, 15(1), 35. https://doi.org/10.14710/jis.15.1.2016.35-52

Rumbiati, \& Heriyana. (2020). Pengaruh Gaya Hidup, dan Kemudahan Terhadap Minat Beli Mahasiswa dalam Berbelanja Online. 1(1), 57-65.

Sakdiyah, M., Frianto, A., \& Ningsih, L. S. R. (2021). Pengaruh Gaya Hidup dan Harga Terhadap Keputusan Pembelian ( Studi Kasus Pada Onlineshop Pusathijabsyaree Surabaya). 3, 226-244.

Sudjatmika, F. V. (2017). Pengaruh Harga, Ulasan Produk, Kemudahan Dan Keamanan Terhadap Keputusan Pembelian Secara Online Di Tokopedia.Com. 5(1).

Sugiyono. (2015). Metode Penelitian Kombinasi (Mix Methods).

Sumarwan, U. (2004). Perilaku Konsumen (Teori dan Penerapannya dalam Pemasaran).

Tambunan, E. (2019). Pengaruh Promosi dan Kualitas Produk Terhadap Minat Beli Mahasiswa Farmasi Pada Kosmetik Wardah Di Universitas Sari Mutiara Indonesia Medan. Foresight, 5(3), 1-9. 